Article

\title{
Sustainable Food Consumption: Investigating Organic Meat Purchase Intention by Vietnamese Consumers
}

\author{
Hoang Viet Nguyen ${ }^{1} \mathbb{D}$, Ninh Nguyen ${ }^{2,3, *}$, Bach Khoa Nguyen ${ }^{3}$ and Steven Greenland ${ }^{4}$ \\ 1 Department of Research Administration, Thuongmai University, Hanoi 100000, Vietnam; nhviet@tmu.edu.vn \\ 2 Department of Economics, Finance and Marketing, La Trobe Business School, Bundoora, VIC 3086, Australia \\ 3 Business Sustainability Research Group, Thuongmai University, Hanoi 100000, Vietnam; nbkhoa@tmu.edu.vn \\ 4 Asia Pacific College of Business and Law, Charles Darwin University, Darwin, NT 0800, Australia; \\ steven.greenland@cdu.edu.au \\ * Correspondence: ninh.nguyen@latrobe.edu.au or ninhnguyen@tmu.edu.vn
}

check for updates

Citation: Nguyen, H.V.; Nguyen, N.; Nguyen, B.K.; Greenland, S. Sustainable Food Consumption: Investigating Organic Meat Purchase Intention by Vietnamese Consumers. Sustainability 2021, 13, 953.

https:/ / doi.org/10.3390/su13020953

Received: 19 December 2020

Accepted: 15 January 2021

Published: 19 January 2021

Publisher's Note: MDPI stays neutral with regard to jurisdictional claims in published maps and institutional affiliations.

Copyright: (c) 2021 by the authors. Licensee MDPI, Basel, Switzerland. This article is an open access article distributed under the terms and conditions of the Creative Commons Attribution (CC BY) license (https:// creativecommons.org/licenses/by/ $4.0 /)$.

\begin{abstract}
Promoting sustainable food consumption contributes to the achievement of the United Nation's Sustainable Development Goals. This study investigated the key determinants of consumer intention to purchase organic meat in an emerging market and a unique model was developed by incorporating environmental concern and guilt with the key components of the Theory of Planned Behavior. This model was then validated by obtaining data from a sample of 402 Vietnamese consumers at five food stores in Ho Chi Minh City, using a paper-based survey. The findings reveal that consumers who are concerned about the environment are likely to formulate favorable attitudes and downplay monetary barriers associated with organic food purchase. In addition, while attitudes and guilt about buying conventional meat have a positive effect on organic meat purchase intention, perceived monetary barriers significantly reduce the intention. These findings highlight both the rational and emotional aspects of organic food purchase intention and have important implications for key stakeholders and the encouragement of organic meat consumption.
\end{abstract}

Keywords: sustainable food consumption; organic food; organic meat; purchase intention; attitudes; subjective norms; emotions; guilt; monetary barriers; emerging markets; Vietnam

\section{Introduction}

Encouraging more sustainable food consumption is critical to future sustainability [1,2]. Fostering the purchase of organic food makes an important contribution to the United Nation's Sustainable Development Goals, especially those relating to sustainable production and consumption. This is because organic agriculture promotes "soil quality, crop rotations, animal and plant diversity, biological processes, and animal welfare, while generally prohibiting irradiation, sewage sludge, genetic engineering, the prophylactic use of antibiotics, and virtually all synthetic pesticides and fertilizers" [3] (p. 1). Given these benefits for environment, human health and animal welfare, consumer demand for organic products has grown substantially. According to the 2019 report by the Research Institute of Organic Agriculture and the International Federation of Organic Agriculture, the global retail sales of organic products have reached over 92 billion euros [4].

Considerable research has sought to identify and examine the various factors influencing organic food purchase intention and consumption using several theories and models such as value theories, rational choice theories (e.g., Knowledge-Attitude-Behavior Model, Theory of Reasoned Action, Theory of Plan Behavior), and normative and ethical models (e.g., Norm Activation Model, Value-Beliefs-Norm Model). Key motivators investigated in prior studies include personal factors (e.g., demographics, personal values, concerns about the environment, health and animal welfare, ethical beliefs, lifestyles, attitudes) and socio-cultural influences (e.g., social norms, media influence, cultural values) [5-12]. 
However, previous research has also pointed out several deterrents, such as consumer rejection of high prices (i.e., monetary barriers), distrust in certified organic labels, skepticism, perceived risks, habits of buying conventional food products, inaccessibility, lack of variety, and insufficient and ineffective marketing from firms [5,7,13-15]. Notably, the impact and importance of these motivators and barriers tend to vary across the contexts of countries and product categories. For instance, Tarkiainen and Sundqvist [16] found that price is not a significant deterrent to organic food purchase intention in a developed country (Finland), while Xie et al. [17] assert that high price is the top-rated reason for not purchasing organic food in a developing country (China). In addition, Yin et al. [18] point out that Chinese consumers demonstrate more safety concerns and higher willingness to pay for organic vegetables and vegetables than organic grains and milks. Possible explanations are that fruits and vegetables are more frequently consumed by consumers and that such products are often reported to have high levels of pesticide residue and toxic chemicals.

The present study aims to investigate the key determinants affecting consumer behavior towards organic food in a specific context, i.e., consumer intention to purchase organic meat in Vietnam. To this end, this study develops and validates a model that combines the key components of the Theory of Planned Behavior (TPB) with guilt and environmental concern. While the TPB constructs (i.e., "attitudes, subjective norms and perceived behavioral control") focus on the utilitarian/rational aspects of organic food purchase intention, environmental concern and guilt address the importance of emotional factors for such an intention. Hence, the findings of this study will contribute to the literature on sustainable food consumption and provide further insights into the role of utilitarian and hedonic motives in organic food purchase and consumption.

This study also enriches the extant knowledge of organic meat consumption in emerging markets, which has received scant attention from food researchers [19]. According to the US Department of Agriculture, organic meat products come from animals that are not subjected to dangerous antibiotics or growth hormones [20], hence, these products are more environmentally friendly and healthier compared to conventional meat. Encouraging organic meat purchase is particularly important in Vietnam, where meat is among the most consumed food products by households [21] and consumers are increasingly concerned about meat products that contain banned antibiotics and residues [22]. The latest data from Euromonitor show that meat consumption reached 4.3 million tons in 2019. Notably, consumer demand for beef has quadrupled over the past decade [23]. The growing consumption of meat products has substantially negative effects on the national environmental quality in terms of greenhouse gas emissions and excessive natural resources utilization [23].

We organized the remaining of this paper as follows. Section 2 discusses theoretical background and develops the research model and associated hypotheses. Section 3 provides a detailed discussion of the research methodology, which consists of measures of constructs investigated, data collection procedure, research ethics, sample and data analysis methods. Section 4 presents results of the data analysis including hypotheses testing, while Section 5 discusses theoretical and managerial implications of the findings. The final section provides key conclusions and directions for future research.

\section{Theories and Hypotheses}

\subsection{Theoretical Background}

The TPB developed by Ajzen [24] posits that behavioral intention can be explained by three factors including attitudes, subjective (social) norms, and perceived behavioral control. According to Ajzen [25], attitudes denote "beliefs about the likely consequences or other attributes of the behavior", whereas subjective norms refer to "beliefs about the normative expectations of other people". Perceived behavioral control (PBC) reflects "the perceived ease of difficulty of performing the behavior" [25] (p. 665). The TPB has proved to be effective in predicting various consumer environmentally sustainable behaviors [26,27], including organic 
food purchase intention and consumption $[28,29]$. Hence, this theory provides a theoretical background for developing a research model examined in the present study.

In accordance with the TPB, attitudes towards purchasing organic food, subjective norms and perceived monetary barriers (which are used to operationalize $\mathrm{PBC}$ ) are expected to affect consumer intention to purchase organic food. Moreover, this study extends the TPB by incorporating environmental concern and guilt into the research model. Environmental concern has been identified as an important determinant of environmentally sustainable behaviors [30,31] and organic food purchase [32,33]. The addition of this construct to the TPB can further explain the formation of green attitudes and purchase intentions [34]. In addition, the inclusion of guilt sheds light on how emotional or affective factors affect organic food purchase intention. This is important because many green consumers and organic food shoppers are motivated by emotions and feelings [28,35,36]. The research model is illustrated in Figure 1. The hypothetical relationships between the variables will be explained in the following sections.

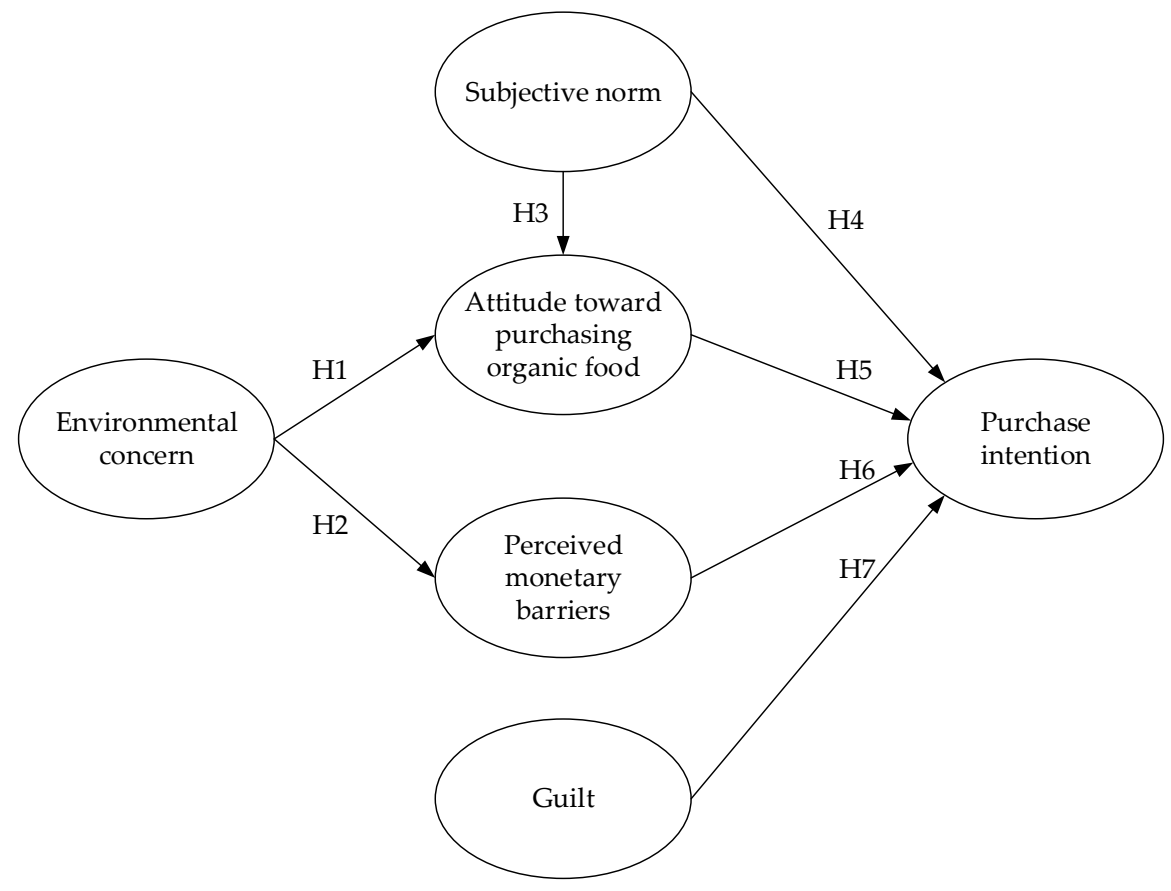

Figure 1. Research model. Source: the current study.

\subsection{Literature Review and Hypotheses Development}

\subsubsection{Environmental Concern}

Consumers' concerns for the environment have been the focus of research in the fields of green purchases and organic food. In its broadest sense, environmental concern denotes "the degree to which people are aware of problems regarding the environment, their support of efforts to solve such problems" [37] (p. 176), and "the affect (i.e., worry) associated with beliefs about environmental problems" [38] (p. 458). Empirical research has operationalized environmental concern as general concerns about environmental quality or specific concerns about environmental problems associated with a behavior or a country [37,39-41]. In general, consumers with greater environmental concern are more likely to engage in environmentally friendly behaviors including organic food consumption.

Several prior studies reveal that environmental concern exerts a positive effect on attitudes associate with organic food and the purchase of this green product [42-44]. Verhoef [45] asserts that environmental concern plays an essential role in consumer choice of organic meat. Kirk and Slade [46] conclude that consumers form positive attitudes towards organic lamb because such an organic meat is environmentally friendly. Magnusson et al. [47] find that consumers' beliefs about the environmental consequences of organic 
food purchases positively impact their attitudes towards purchasing organic meat. Hence, we formulated the first hypothesis as follows:

Hypothesis 1 (H1). Environmental concern is positively related to attitudes towards organic meat purchase.

Consumers who are concerned about environmental quality are less likely to care about barriers and inconvenience associated with green purchases [48,49]. This is because these consumers tend to assign greater importance to collective outcomes (i.e., better environmental quality) than personal costs such as monetary costs [50]. Scholars such as Perlaviciute and Steg [51] and Van der Werff et al. [52] demonstrate that consumers who endorse environmental values favor environmentally friendly products despite their higher prices. A consumer survey confirms a negative correlation between consumers' environmental concern and their perceptions of the higher monetary costs associated with organic meat purchase [19]. We therefore formulated the second hypothesis as follows:

Hypothesis 2 (H2). Environmental concern is negatively related to perceived monetary barriers associated with organic meat purchase.

\subsubsection{Subjective Norms}

Subjective norms represent pressure to or not to perform an action from others who are important to an individual. Such a social influence is important to the development of consumers' pro-environmental attitudes and actions [53]. In the context of organic food choice, subjective norms have been found to have a positive impact on attitude towards buying organic bread and flour [16]. Lodorfos and Dennis [54] assert that it is important to include subjective norms in models predicting organic food purchase since the pressure from important persons (e.g., friends and family) influence both attitude and purchase behavior. They also found a positive correlation between subjective norms and attitudes among consumers of organic products such as fruits, vegetables and meat. Hence, we proposed the following hypothesis:

Hypothesis 3 (H3). Subjective norms are positively related to attitudes towards organic meat purchase.

The TPB posits that subjective norms have a direct impact on consumer behavioral intention. Several empirical studies have confirmed the significance of subjective norms and social pressure in the formation of purchase intentions towards green products including organic food [49,55,56]. Two consumer surveys conducted by Kirk et al. [57] and Wong and Aini [58] revealed that subjective norms significantly enhance consumer intention to purchase organic meat. We therefore proposed the following hypothesis:

Hypothesis 4 (H4). Subjective norms are positively related to intention to purchase organic meat.

\subsubsection{Attitudes}

Attitudes represent favorable or unfavorable evaluation of an object or behavior. Consumers' attitudes are essential in the purchase of organic food since they often need to understand their beliefs and motives to overcome the barriers associated with this behavior [59]. Tarkiainen and Sundqvist [16] report that attitudes towards buying organic food are the strongest predictor of purchase intention. A regression analysis performed by Kirk et al. [57] shows that consumers' attitudes have a positive effect on their intentions to purchase organic meat. Thus, we suggested the following hypothesis:

Hypothesis 5 (H5). Attitudes towards organic meat purchase are positively related topurchase intention. 


\subsubsection{Perceived Monetary Barriers}

Consumers may not intend to purchase green products, owing to several barriers and inconvenience relating to money, time, product availability, risk and unreliable ecolabels [60-62]. Perceived monetary barriers refer to consumers' perceptions of the high price of green products and their ability to afford these products [63]. Notably, many consumers perceive monetary barriers associated with organic food purchase as they cannot afford to pay more for organic food which is more expensive than conventional food [63]. While Apostolidis and McLeay [64] assert that that price substantially affects consumer choices toward organic meat, Verhoef [45] found that perceived price level negatively affects consumer choice of such a product. McEachern and Schröder [65] emphasize that despite their awareness of environmental benefits of organic meat, many consumers cannot afford this product and refuse to pay more for it. Thus, we proposed the following hypothesis:

Hypothesis 6 (H6). Perceived monetary barriers are negatively related to purchase intention.

\subsubsection{Guilt about Consuming Conventional Meat}

Baumeister et al. [66] refer to guilt as "an individual's unpleasant emotional state associated with possible objections to one's own actions, inaction, circumstances, or intentions" (p. 245). Guilt may arise when individuals perceive that their actions have violated certain social standard or moral norms [67]. Regular purchase and consumption of conventional meat instead of organic one can make consumers feel guilty since they care about environmental quality and welfare of animals, and such action is against their moral and ethical standards $[45,68]$. Hence, consumers might want to purchase organic meat to avoid this negative feeling [45]. Hence, we formulated the hypothesis below:

Hypothesis 7 (H7). Guilt about consuming conventional meat is positively related to purchase intention.

In sum, various hypotheses have been developed as a result of the critical review of relevant research in the areas of pro-environmental behavior, sustainable food consumption, and organic food purchase. Table 1 summarizes all the hypotheses proposed in the current study.

Table 1. Summary of research hypotheses.

\begin{tabular}{cc}
\hline No. & Hypotheses \\
\hline H1 & Environmental concern is positively related to attitudes towards organic meat purchase. \\
H2 & Environmental concern is negatively related to perceived monetary barriers associated with organic meat purchase. \\
H3 & Subjective norms are positively related to attitudes towards organic meat purchase. \\
H4 & Subjective norms are positively related to intention to purchase organic meat. \\
H5 & Attitudes towards organic meat purchase are positively related to purchase intention. \\
H6 & Perceived monetary barriers are negatively related to purchase intention. \\
H7 & Guilt about consuming conventional meat is positively related to purchase intention. \\
\hline
\end{tabular}

Source: the current study.

\section{Research Methods}

\subsection{Measures of the Constructs}

We used previously validated scales to measure the constructs presented in the research framework and backward translation between English and Vietnam to design the questionnaire [69]. Specifically, four items were adapted from Lee [41] and Pham et al. [9] to measure country-specific environmental concern (i.e., concern about Vietnam's environment). For attitude towards purchasing organic meat, another four items were adopted from research studies performed by Dean et al. [70] and Arvola et al. [55]. Subjective norms were measured by three items suggested by Arvola [55] and Yadav [44]. Another three items were adopted from Verhoef [45] and Tanner and Kast [63] to measure perceived 
monetary barriers. Guilt about consuming conventional meat was measured using four items suggested by Verhoef [45]. Specifically, respondents were presented with a scenario that they had purchased conventional meat instead of organic meat, and then asked to indicate the extent to which they felt guilty about that behavior. Finally, purchase intention was operationalized using four items from Nguyen et al. [27] and Pham et al. [9]. To measure guilt, we used a 7-point scale which is anchored at 1 for 'to a very low extent' and 7 for "to a very high extent". For other constructs, a 7-point Likert scale, anchoring at 1 for "strongly disagree" to 7 for "strongly agree", was used.

Although the aforementioned scales have proved to be valid and reliable in previous studies, the first author conducted two focus groups with organic food consumers and professors of marketing to detect possible issues of utilizing the items in the emerging context of Vietnam. Each focus group consisted of five participants and lasted around $60 \mathrm{~min}$ each. There were no problems relating to the scales identified during the focus groups. Hence, all the items (which are shown in the next section) were included in the final questionnaire.

\subsection{Data Collection and Sample}

Prior to data collection, the research protocol including sampling method and data collection procedure was reviewed and approved by Vietnam Foundation for Science and Technology Development in September 2018 (NAFOSTED 502.02-2018.303). We used paper-based questionnaire to collect data from Vietnamese consumers aged over 18 years, who were interested in organic meat. We first conducted a pilot test to identify potential problems with administration and completion of the questionnaire. Specifically, we invited a total of 24 consumers, who voluntarily agreed to participate in the pilot test, to answer the questions, comment on the wording and meanings of the items of measure and the time of completing the questionnaire.

In the main study, we recruited ten experienced research assistants to interview shoppers at five food stores selling organic meat in Ho Chi Minh city, which is the largest city located in the South of Vietnam. Consumers in big cities such as Ho Chi Minh city prove to be suitable subjects in previous studies relating to green consumption, since they are generally aware of environmental issues and earn a higher income than the national average $[49,71,72]$. Given that it was not possible to obtain an appropriate sampling frame consisting of the shoppers, we adopted convenience sampling which had been used for studying organic food purchase and consumer behavior at retail stores [42,73,74]. Zikmund et al. [75] propose that sample size can be determined based on population size and sample proportion. Accordingly, the target sample size for our study was 400, which would generate a $95 \%$ confidence level with a margin of error of about $\pm 5 \%$ points.

The research assistants approached every fourth consumers who entered the stores and requested them to voluntarily complete the questionnaire. Consumers were informed that they were free to stop providing their answers at any time, and that completion of the questionnaire was taken as "informed consent". We collected a total of 410 surveys during about two months. The data screening procedure included checking for missing data, normality of distribution and outliers. While there were no missing data and univariate outliers, the results of measuring Mahalanobis distance show that 8 surveys included multivariate outliers. Hence, the final valid sample consisted of 402 respondents, which met the target sample size.

\subsection{Data Analysis Procedure}

The data collected from 402 respondents were subjected to a series of analyses using SPSS 25.0 and AMOS 25.0 (IBM, Armonk, NY, USA). We initially described the characteristics of the sample size. After that, we performed Harman's single factor and latent common methods factor to examine potential common method variance. This was followed by descriptive statistics and reliability analysis. We then conducted a confirmatory 
factor analysis (CFA) to evaluate construct validity. Finally, the proposed hypotheses were examined by structural equation modelling (SEM).

\section{Results}

\subsection{Sample Profile}

Table 2 illustrates the final sample's demographic characteristics. Our sample included 192 males $(47.8 \%)$ and 210 females $(52.2 \%)$, which closely resembles the sex ratio (99 males per 100 females) in the national population reported by the General Statistics Office of Vietnam [76]. Concerning age, approximately $31 \%$ were in the $18-29$ age category, and $24 \%$ aged 50 years and older. This reflected the young population of Vietnam [76]. In addition, around $60 \%$ of the respondents were currently married, while $45 \%$ had undergraduate degrees. These figures are similar to previous studies of environmentally friendly behavior and green purchases in Vietnam [48,77].

Table 2. Respondents' demographic characteristics.

\begin{tabular}{ccc}
\hline & Frequencies & Percentages \\
\hline Gender & 192 & 47.8 \\
Male & 210 & 52.2 \\
Female & & \\
Age & 123 & 30.6 \\
$18-29$ & 98 & 24.4 \\
$30-39$ & 84 & 20.9 \\
$40-49$ & 97 & 24.1 \\
50 and above & & \\
Marital status & 120 & 29.8 \\
Single/never married & 240 & 59.7 \\
Currently married & 42 & 10.5 \\
Others & & \\
Level of education & 22 & 5.5 \\
High school or lesser & 131 & 32.6 \\
Diploma & 181 & 45.0 \\
Undergraduate & 68 & 16.9 \\
Postgraduate & & \\
\hline None & 131 & 32.6 \\
None & 135 & 33.6 \\
1 child & 81 & 20.1 \\
2 children & 45 & 11.2 \\
\hline and more children & 10 & 2.5 \\
\hline Number of dependents in household & &
\end{tabular}

Note: $n=402$. Source: the current study.

\subsection{Common Method Variance}

Common method variance (bias) may affect sample data which are collected using self-reported methods [78]. We therefore applied different statistical techniques to detect the possible impact of this problem. Initially, according to the Harman's single factor test, we performed an exploratory factor analysis (EFA) on all the items [79]. The EFA results indicated that the single factor explained around $30 \%$ of the variance in the variables, indicating that common method bias was unlikely to be a problem in this study [80].

In addition, a CFA was applied to conduct the latent common method factor test which further evaluated the potential problem of common method bias. We allowed all the items to load on their respective variables and on an unmeasured common method factor [68]. We then compared the "standardized regression weights" ( $\beta)$ in the model with the common method factor with those in the model without the factor. Differences between the $\beta$ values were all less than 0.2 , suggesting that common method variance did not have a substantial impact on the sample data [81]. 


\subsection{Descriptive Statistics and Construct Reliability and Validity}

Table 3 shows the results of the descriptive statistics including mean and standard deviation, and reliability coefficient values. The Cronbach's Alpha $(\alpha)$ values (ranging from 0.781 to 0.856 ) were all greater than the suggested threshold of 0.7 [82]. These findings suggest a good internal consistency of reliability for all the construct measures.

Table 3. Items and properties.

\begin{tabular}{|c|c|c|c|c|}
\hline Variables and Items & FLs & Mean & SD & $\alpha$ \\
\hline Environmental concern & & 4.668 & 1.238 & 0.854 \\
\hline “Vietnam's environment is my major concern & 0.804 & & & \\
\hline I am worried about the worsening of the quality of Vietnam's environment & 0.779 & & & \\
\hline I am emotionally involved in environmental protection issues in Vietnam & 0.802 & & & \\
\hline I often think about how the environmental quality in Vietnam can be improved" & 0.706 & & & \\
\hline Attitudes towards purchasing organic meat & & 4.615 & 1.213 & 0.837 \\
\hline "Purchasing organic meat instead of conventional meat is beneficial & 0.799 & & & \\
\hline Purchasing organic meat instead of conventional meat is a wise choice & 0.736 & & & \\
\hline Purchasing meat instead of conventional meat make me feel pleased & 0.715 & & & \\
\hline Purchasing organic meat instead of conventional meat make me feel good" & 0.757 & & & \\
\hline Subjective norms & & 4.850 & 1.197 & 0.781 \\
\hline "Most people who are important to me think that I should buy organic meat & 0.756 & & & \\
\hline Most people who are important to me want me to purchase organic meat & 0.688 & & & \\
\hline Most people whose opinion I value prefer that I should buy organic meat" & 0.771 & & & \\
\hline \multirow{4}{*}{$\begin{array}{l}\text { The price of organic meat is a barrier to purchase it } \\
\text { People should purchase organic meat, even though they are more expensive than } \\
\text { conventional meat" }\end{array}$} & & 3.226 & 1.102 & 0.794 \\
\hline & 0.718 & & & \\
\hline & 0.755 & & & \\
\hline & 0.779 & & & \\
\hline Guilt about purchasing conventional meat & & 3.134 & 1.042 & 0.856 \\
\hline “Troubled mind & 0.798 & & & \\
\hline Guilty & 0.753 & & & \\
\hline Unpleasant & 0.788 & & & \\
\hline Regret" & 0.757 & & & \\
\hline Purchase intention & & 5.001 & 1.023 & 0.822 \\
\hline “I will consider buying organic meat & 0.731 & & & \\
\hline I am willing to buy organic meat instead of conventional meat while shopping & 0.737 & & & \\
\hline I intend to purchase organic meat & 0.738 & & & \\
\hline I will make an effort to buy organic meat in my next purchase" & 0.723 & & & \\
\hline
\end{tabular}

Note: $n=402$; FLs: factor loadings; SD: standard deviation. Source: the current study.

The measurement model was established using CFA. The resultant fit indices (Chisquare $\left(\chi^{2}\right)=274.113$; "Chi-square to degree of freedom ratio" $\left(\chi^{2} / d f\right)=1.413$; "Goodnessof-fit index" (GFI) = 0.920; "Adjusted goodness-of-fit index" (AGFI) $=0.927$; “Tucker and Lewis index" (TLI) $=0.975$; “Comparative fit index" $(\mathrm{CFI})=0.979$; “Root-mean-square error of approximation" (RMSEA) $=0.032$ ) showed that the measurement model represented a good fit [83].

The CFA results enable the calculation of composite reliability $(\mathrm{CR})$ and average variance extracted (AVE), which are illustrated in Table 4. Convergent validity was assessed on the basis of factor loadings (FLs), CR and AVE. The FLs (0.688-0.804) were well above the suggested threshold of 0.6 [84]. The values of CR (0.783-0.857) and AVE (0.536-0.599) also met the recommended criteria suggested by Hair et al. [82]. Hence, the constructs' convergent validity was ensured. Additionally, their discriminant validity was also confirmed, given that the square root of AVE of each construct was greater than the bivariate correlations between the constructs $[82,83]$. Finally, multicollinearity was not a problem because all the correlation values were less than 0.70 [85]. 
Table 4. Descriptive statistics and discriminant validity.

\begin{tabular}{lcccccccc}
\hline & CR & AVE & (1) & (2) & (3) & (4) & (5) & (6) \\
\hline (1) Environmental concern & 0.856 & 0.599 & 0.774 & & & & & \\
(2) Attitudes & 0.839 & 0.566 & 0.466 & 0.752 & & & & \\
(3) Subjective norms & 0.783 & 0.546 & 0.295 & 0.339 & 0.739 & & & \\
(4) Perceived monetary barriers & 0.795 & 0.564 & -0.388 & -0.446 & -0.211 & 0.751 & & \\
(5) Guilt & 0.857 & 0.599 & 0.320 & 0.380 & 0.690 & -0.422 & 0.774 & \\
(6) Purchase intention & 0.822 & 0.536 & 0.241 & 0.453 & 0.401 & -0.402 & 0.620 & 0.732 \\
\hline
\end{tabular}

Note: $n=402$; CR: composite reliability; AVE: average variance extracted; Diagonal value indicates the square root of AVE of construct. Source: the current study.

\subsection{Path Analysis and Hypotheses Testing}

We conducted SEM to test the hypotheses. The fit indices for the structural model met the recommended levels: $\chi^{2}=521.234 ; \chi^{2} / d f=2.580 ; \mathrm{GFI}=0.902 ; \mathrm{TLI}=0.905 ; \mathrm{CFI}=0.917$; RMSEA $=0.063$. Table 5 summarizes the findings of the SEM results and hypotheses.

Table 5. Path analysis and hypotheses testing.

\begin{tabular}{lllcccc}
\hline \multicolumn{2}{c}{ Hypotheses } & $\beta$ & $t$-Value & $p$-Value & Findings \\
\hline H1: Environmental concern & $\rightarrow$ & Attitude & 0.454 & 7.841 & $* * *$ & Supported \\
H2: Environmental concern & $\rightarrow$ & Monetary barriers & -0.404 & -6.429 & $* * *$ & Supported \\
H3: Subjective norms & $\rightarrow$ & Attitude & 0.292 & 5.045 & $* * *$ & Supported \\
H4: Subjective norms & $\rightarrow$ & Purchase intention & 0.018 & 0.306 & 0.759 & Not supported \\
H5: Attitudes & $\rightarrow$ & Purchase intention & 0.252 & 4.216 & $* * *$ & Supported \\
H6: Monetary barriers & $\rightarrow$ & Purchase intention & -0.132 & -2.334 & $*$ & Supported \\
H7: Guilt & $\rightarrow$ & Purchase intention & 0.515 & 8.314 & $* * *$ & Supported \\
\hline
\end{tabular}

Note: $n=402 ;{ }^{* * *} p<0.001 ;{ }^{*} p<0.05$. Source: the current study.

Environmental concern had a significant and positive influence on attitudes towards purchasing organic meat $(\beta=0.454, t=7.841, p<0.001)$ and a negative impact on perceived monetary barriers $(\beta=-0.404, t=-6.429, p<0.001)$. Hence, $\mathrm{H}_{1}$ and $\mathrm{H}_{2}$ were supported. Subjective norms were significantly positively related to attitudes $(\beta=0.292, t=5.045$, $p<0.001$ ), providing support for $\mathrm{H}_{3}$. However, the positive relationship between subjective norms and purchase intention was not significant $(\beta=0.018, t=0.306, p>0.05)$, rejecting $\mathrm{H}_{4}$. In support of $\mathrm{H}_{5}$ and $\mathrm{H}_{7}$, attitudes $(\beta=0.252, t=4.216, p<0.001)$ and guilt $(\beta=0.515$, $t=8.314, p<0.001$ ) exerted a significant and positive impact on purchase intention. Finally, the association between money barriers and purchase intention was negative and significant $(\beta=-0.132, t=-2.334, p<0.05)$. This result confirmed $\mathrm{H}_{6}$.

\section{Discussion of Findings}

\subsection{Discussion and Theoretical Implications}

This study contributes to the limited knowledge of organic meat consumption in emerging markets [19] via investigation of consumer attitudes and behavior in Vietnam, which is a sizeable country in the Southeast Asian region. The primary objective was to determine the factors that enhance or impede consumer intention to purchase organic meat. This study provided insights via application of the TPB including attitudes, subjective (social) norms, and perceived behavioral control. It also provided insights into organic meat consumption and purchase by considering the relevance of utilitarian and hedonic motives to organic meat consumption. A unique model was initially developed that combined the key components of the TPB, which have been widely used in organic food research [29], with environmental concern and emotion (i.e., guilt). This model was then validated via a survey of Vietnamese consumers.

In terms of theoretical contribution, the analysis revealed support for six of the seven research hypotheses. The important role of environmental concern (i.e., concern about Vietnam's environment) in consumer decisions towards purchasing organic food was confirmed. Specifically, environmental concern was found to enhance attitudes and reduce 
perceived monetary barriers associated with organic meat purchase. This finding supports the assertion that consumers who care about environmental values and quality tend to develop positive attitudes and downplay the barriers related to pro-environmental behavior $[49,50]$. It also extends previous research on the positive impact of environmental concern on attitudes towards buying organic food products including organic meat in both developed and developing markets $[19,42,43,86,87]$.

The results also reveal that the TPB is relevant for explaining organic food purchase intention in the context of emerging markets. Attitude had the strongest influence on intention to purchase organic meat, which echoes the findings of a meta-analysis conducted by Scalco et al. [29] that also identified attitude as the most relevant determinant of organic food buying intention. Interestingly, subjective norms in this study were not a significant direct predictor of purchase intention. While this contradicts some prior research about the role of subjective norms in organic food purchase in developed countries $[42,54,55,88]$, a possible explanation is that purchasing organic food has not become a social norm in developing countries [86], including Vietnam. The results in this study however show that subjective norms positively impact attitudes, which supports the finding of Tarkiainen and Sundqvist [16]. This implies that Vietnamese consumers take into account the opinions of important others in their evaluation of organic meat purchase, which can be explained by Vietnam's strong collectivist culture that emphasizes interpersonal relationships [89]. In line with some previous research into organic food [58] and organic meat [45], this study's findings confirmed the negative relationship between perceived monetary barriers and organic meat buying intention. While many consumers in developed countries are willing to pay a high for organic food [90], the finding suggests that Vietnamese consumers still find organic meat expensive and they cannot afford to pay more for it. Indeed, monetary barriers have been widely acknowledged as a serious deterrent to green purchases in developing markets, given the widespread financial constraints in these countries [61]. Thøgersen et al. [91] also point out that consumers with lower income tend to be more price sensitive when purchasing organic food.

The final important finding concerns the significant and positive impact of guilt on green purchase intention. Consumers may feel guilty, unpleasant and regret about the purchase and consumption of conventional meat products, which are detrimental to environmental quality and animal welfare [23]. Such negative feelings encourage them to purchase environmentally friendly and ethically produced products such as organic meat. This finding echoes the research of Verhoef [45] and provides further evidence of the significant role played by emotional factors in relation to pro-environmental consumption behavior $[35,92]$ and organic food purchase [28,93]. It also suggests to the value of incorporating emotional factors like guilt into the TPB for better understanding consumer intention to purchase organic food. Collectively, the findings of this study have highlighted the motivational complexity (including both utilitarian and hedonic motives) of organic food purchase and consumption behavior.

\subsection{Discussion and Practical Implications}

Regarding practical implications, this research has the capacity to facilitate the promotion of positive environmental outcomes by facilitating more effective promotion of organic meat consumption. Organically farmed meat is produced in a much more sustainable manner compared to conventional meat production [20]. This is particularly pertinent in Vietnam where rising meat consumption has been identified as a significant future sustainability issue demanding further investigation in order to reduce associated environmentally detrimental greenhouse gas emissions and excessive natural resources utilization [23]. The greater understanding of organic meet consumption afforded by the research findings can therefore help marketers, policymakers and environmental groups to foster organic food (meat) purchase.

In keeping with recommendations by other researchers [94], the findings of this study can help the Vietnamese government to develop more effective consumer education and 
information programs. These might include national school education programs regarding the sustainability benefits of organic food consumption to help shape favorable sustainable attitudes and behavior in children.

Effective marketing communication for organic food is also critical in the promotion of more sustainable behavior $[94,95]$ since advertising and communications play such significant roles in determining food product consumption [96]. Also as acknowledged by other studies $[97,98]$ effective integrated multi-media public awareness campaigns offer strong potential for promoting organic food consumption, particularly when used in conjunction with appropriate packaging information and trustworthy certification. These messages and information can be effectively communicated to consumers via appropriate media channels (e.g., TV, radio, internet and social media), in-store brochures and displays.

In terms of communication strategy and message content, given the significance of specific environmental concern, it is important to increase consumer awareness and care for environmental issues nationally. In this regard, joint efforts between the key stakeholders should be made to develop and implement environmental education and communication programs, which provide information and facts about the major problems such climate change, depletion of natural resources and air pollution that Vietnam has been facing. Communication programs should highlight how the production of conventional meat affects animal welfare and the environment in terms of greenhouse gas emissions, land and water utilization and other pollution dimensions. This can trigger the feelings of guilt and regret about purchasing and consuming traditional meat products, which in turn enhance the purchase intention and behavior towards organic meat.

To enhance consumer attitudes towards organic meat purchase, producers and retailers should deliver clear and compelling messages to consumers that organic meat is better for the environment, animal welfare and human health than conventional meat products. They should also communicate that more people are consuming organic foods, and that their family, friends and neighbors are purchasing organic products. This will help increase consumer perception of social norms, which in turn enhances their attitudes towards organic meat purchase.

Given the monetary barriers perceived by consumers to be associated with organic purchases, firms should endeavor to reduce the price of organic meat products by improving production and distribution efficiency. Manufacturers and retailers should also enhance the value perception of organic meat. by strictly adhering to organic agricultural standards, which will help to convince consumers that it is worth paying more for organic meat compared to conventionally produced products.

\section{Conclusions}

This study makes a contribution to the growing sustainable food consumption literature and enriches the current knowledge about consumer intention to purchase organic food in developing and emerging markets. It provides support for an extended TPB model to predict organic meat purchase intention in the emerging context of Vietnam. The present study highlights the relevance of incorporating environmental concern and guilt to the TPB factors (i.e., attitudes, subjective norms and perceived monetary barriers) in order to better explain the intention to purchase organic food. It also offers further insights into the rational, emotional and social motivations, as well as monetary barriers, associated with organic food consumption.

\section{Limitations and Future Research Directions}

This study, however, has some limitations. First, the sample, while representative of Vietnam's most populous city, is unlikely to be representative of the overall population. Future research should therefore seek to obtain data from both urban and rural consumers in different regions. Second, this study examines only one emotional factor (i.e., guilt), which can be extended in future studies to include other relevant emotional determinants such as fear, empathy and other more positive emotions. Third, although focusing on 
perceived monetary barriers proved to be effective in explaining organic meat purchase intention, future research can investigate other potential deterrents such as the limited availability of organic products and consumer distrust in organic product labelling. Finally, future research can test the model validated in this study in other contexts, such as organic meat purchases in other emerging markets, consumer intention to purchase plant-based organic food, as well as the wider range of organically grown non-food products.

Author Contributions: Conceptualization, H.V.N., S.G., B.K.N. and N.N.; methodology, H.V.N., S.G., B.K.N. and N.N.; formal analysis, H.V.N. and N.N.; investigation, H.V.N.; writing-original draft preparation, H.V.N., S.G., B.K.N. and N.N.; writing-review and editing, H.V.N., S.G., B.K.N. and N.N.; funding acquisition, H.V.N., B.K.N. and N.N. All authors have read and agreed to the published version of the manuscript.

Funding: This research is funded by Vietnam National Foundation for Science and Technology Development (NAFOSTED) under grant number 502.02-2018.303.

Institutional Review Board Statement: The study was conducted according to the guidelines of the Declaration of Helsinki, and approved by Vietnam Foundation for Science and Technology Development (NAFOSTED 502.02-2018.303).

Informed Consent Statement: Informed consent was obtained from all subjects involved in the study.

Data Availability Statement: The data presented in this study are available on request from the corresponding author.

Conflicts of Interest: The authors declare no conflict of interest.

\section{References}

1. Nguyen, N.; Johnson, L.W. Consumer behaviour and environmental sustainability. J. Consum. Behav. 2020, 19, 539-541. [CrossRef]

2. Rahman, S.U.; Luomala, H. A comparison of motivational patterns in sustainable food consumption between pakistan and finland: Duties or self-reliance? J. Int. Food Agribus. Mark. 2020, 1-28. [CrossRef]

3. Reganold, J.P.; Wachter, J.M. Organic agriculture in the twenty-first century. Nat. Plants 2016, 2, 1-8. [CrossRef] [PubMed]

4. Willer, H.; Lernoud, J. The World of Organic Agriculture, STATISTICS and Emerging Trends 2019; Research Institute of Organic Agriculture (FiBL) and IFOAM-Organics International: Frick, Switzerland; Bonn, Germany, 2019.

5. Hughner, R.S.; McDonagh, P.; Prothero, A.; Shultz, C.J.; Stanton, J. Who are organic food consumers? A compilation and review of why people purchase organic food. J. Consum. Behav. 2007, 6, 94-110. [CrossRef]

6. Rana, J.; Paul, J. Consumer behavior and purchase intention for organic food: A review and research agenda. J. Retail. Consum. Serv. 2017, 38, 157-165. [CrossRef]

7. Kushwah, S.; Dhir, A.; Sagar, M.; Gupta, B. Determinants of organic food consumption. A systematic literature review on motives and barriers. Appetite 2019, 143, 104402. [CrossRef]

8. Golob, U.; Kos Koklic, M.; Podnar, K.; Zabkar, V. The role of environmentally conscious purchase behaviour and green scepticism in organic food consumption. Br. Food J. 2018, 120, 2411-2424. [CrossRef]

9. Pham, T.H.; Nguyen, T.N.; Phan, T.T.H.; Nguyen, N.T. Evaluating the purchase behaviour of organic food by young consumers in an emerging market economy. J. Strateg. Mark. 2019, 27, 540-556. [CrossRef]

10. Nosi, C.; Zollo, L.; Rialti, R.; Ciappei, C. Sustainable consumption in organic food buying behavior: The case of quinoa. Br. Food J. 2020, 122, 976-994. [CrossRef]

11. Katt, F.; Meixner, O. A systematic review of drivers influencing consumer willingness to pay for organic food. Trends Food Sci. Technol. 2020, 100, 374-388. [CrossRef]

12. Molinillo, S.; Vidal-Branco, M.; Japutra, A. Understanding the drivers of organic foods purchasing of millennials: Evidence from brazil and spain. J. Retail. Consum. Serv. 2020, 52, 101926. [CrossRef]

13. Nguyen, T.T.H.; Yang, Z.; Nguyen, N.; Johnson, L.W.; Cao, T.K. Greenwash and green purchase intention: The mediating role of green skepticism. Sustainability 2019, 11, 2653. [CrossRef]

14. Bryła, P. Organic food consumption in poland: Motives and barriers. Appetite 2016, 105, 737-746. [CrossRef]

15. Van Doorn, J.; Verhoef, P.C. Drivers of and barriers to organic purchase behavior. J. Retail. 2015, 91, 436-450. [CrossRef]

16. Tarkiainen, A.; Sundqvist, S. Subjective norms, attitudes and intentions of finnish consumers in buying organic food. Br. Food J. 2005, 107, 808-822. [CrossRef]

17. Xie, B.; Wang, L.; Yang, H.; Wang, Y.; Zhang, M. Consumer perceptions and attitudes of organic food products in eastern china. Br. Food J. 2015, 117, 1105-1121. [CrossRef]

18. Yin, S.; Wu, L.; Du, L.; Chen, M. Consumers' purchase intention of organic food in china. J. Sci. Food Agric. 2010, 90, 1361-1367. [CrossRef] 
19. Nguyen, H.V.; Nguyen, N.; Nguyen, B.K.; Lobo, A.; Vu, P.A. Organic food purchases in an emerging market: The influence of consumers' personal factors and green marketing practices of food stores. Int. J. Environ. Res. Public Health 2019, $16,1037$. [CrossRef]

20. Ursachi, G.; Horodnic, I.A.; Zait, A. How reliable are measurement scales? External factors with indirect influence on reliability estimators. Procedia Econ. Financ. 2015, 20, 679-686. [CrossRef]

21. GSO. Vietnam Household Living Standards Survey 2012; General Satistics Office of Vietnam: Hanoi, Vietnam, 2012.

22. Nguyen-Viet, H.; Tuyet-Hanh, T.T.; Unger, F.; Dang-Xuan, S.; Grace, D. Food safety in vietnam: Where we are at and what we can learn from international experiences. Infect. Dis. Poverty 2017, 6, 39. [CrossRef]

23. Sharma, R.; Nguyen, T.T.; Grote, U. Changing consumption patterns-drivers and the environmental impact. Sustainability 2018, 10, 4190. [CrossRef]

24. Ajzen, I. From Intentions to Actions: A Theory of Planned Behavior. In Action Control: From Cognition to Behavior; Kuhl, J., Beckmann, J., Eds.; Springer: Berlin/Heidelberg, Gemany, 1985; pp. 11-39.

25. Ajzen, I. Perceived behavioral control, self-efficacy, locus of control, and the theory of planned behavior. J. Appl. Soc. Psychol. 2002, 32, 665-683. [CrossRef]

26. Nguyen, Q.A.; Hens, L.; Nguyen, N.; MacAlister, C.; Lebel, L. Explaining intentions by vietnamese schoolchildren to adopt pro-environmental behaviors in response to climate change using theories of persuasive communication. Environ. Manag. 2020, 66, 845-857. [CrossRef] [PubMed]

27. Nguyen, T.N.; Lobo, A.; Greenland, S. The influence of cultural values on green purchase behaviour. Mark. Intell. Plan. 2017, 35, 377-396. [CrossRef]

28. Aertsens, J.; Verbeke, W.; Mondelaers, K.; Van Huylenbroeck, G. Personal determinants of organic food consumption: A review. Br. Food J. 2009, 111, 1140-1167. [CrossRef]

29. Scalco, A.; Noventa, S.; Sartori, R.; Ceschi, A. Predicting organic food consumption: A meta-analytic structural equation model based on the theory of planned behavior. Appetite 2017, 112, 235-248. [CrossRef]

30. Dunlap, R.; Jones, R. Environmental concern: Conceptual and measurement issues. In Handbook of Environmental Sociology; Dunlap, R.E., Michelson, W., Eds.; Greenwook Press: London, UK, 2012; pp. 482-542.

31. Nguyen, T.N.; Lobo, A.; Nguyen, H.L.; Phan, T.T.H.; Cao, T.K. Determinants influencing conservation behaviour: Perceptions of vietnamese consumers. J. Consum. Behav. 2016, 15, 560-570. [CrossRef]

32. Biermann, G.; Rau, H. The meaning of meat: (Un)sustainable eating practices at home and out of home. Appetite 2020, 153, 104730. [CrossRef]

33. Janssen, M. Determinants of organic food purchases: Evidence from household panel data. Food Qual. Prefer. 2018, 68, 19-28. [CrossRef]

34. Paul, J.; Modi, A.; Patel, J. Predicting green product consumption using theory of planned behavior and reasoned action. J. Retail. Consum. Serv. 2016, 29, 123-134. [CrossRef]

35. Carrus, G.; Passafaro, P.; Bonnes, M. Emotions, habits and rational choices in ecological behaviours: The case of recycling and use of public transportation. J. Environ. Psychol. 2008, 28, 51-62. [CrossRef]

36. Lee, H.-J.; Yun, Z.-S. Consumers' perceptions of organic food attributes and cognitive and affective attitudes as determinants of their purchase intentions toward organic food. Food Qual. Prefer. 2015, 39, 259-267. [CrossRef]

37. Rhead, R.; Elliot, M.; Upham, P. Assessing the structure of uk environmental concern and its association with pro-environmental behaviour. J. Environ. Psychol. 2015, 43, 175-183. [CrossRef]

38. Schultz, P.W.; Gouveia, V.V.; Cameron, L.D.; Tankha, G.; Schmuck, P.; Franěk, M. Values and their relationship to environmental concern and conservation behavior. J. Cross-Cult. Psychol. 2005, 36, 457-475. [CrossRef]

39. Milfont, T.L.; Duckitt, J.; Cameron, L.D. A cross-cultural study of environmental motive concerns and their implications for proenvironmental behavior. Environ. Behav. 2006, 38, 745-767. [CrossRef]

40. Albayrak, T.; Aksoy, Ş.; Caber, M. The effect of environmental concern and scepticism on green purchase behaviour. Mark. Intell. Plan. 2013, 31, 27-39. [CrossRef]

41. Lee, K. Opportunities for green marketing: Young consumers. Mark. Intell. Plan. 2008, 26, 573-586. [CrossRef]

42. Smith, S.; Paladino, A. Eating clean and green? Investigating consumer motivations towards the purchase of organic food. Australas. Mark. J. AMJ 2010, 18, 93-104. [CrossRef]

43. Chen, M.F. Attitude toward organic foods among taiwanese as related to health consciousness, environmental attitudes, and the mediating effects of a healthy lifestyle. Br. Food J. 2009, 111, 165-178. [CrossRef]

44. Yadav, R. Altruistic or egoistic: Which value promotes organic food consumption among young consumers? A study in the context of a developing nation. J. Retail. Consum. Serv. 2016, 33, 92-97. [CrossRef]

45. Verhoef, P.C. Explaining purchases of organic meat by dutch consumers. Eur. Rev. Agric. Econ. 2005, 32, 245-267. [CrossRef]

46. Kirk, J.; Slade, K. An investigation into uk consumer perception of organic lamb. In Organic Meat and Milk from Ruminants; Kyriazakis, I., Zervas, G., Eds.; Wageningen Academic Publishers: Wageningen, The Netherlands, 2001; pp. $157-161$.

47. Magnusson, M.K.; Arvola, A.; Hursti, U.K.K.; Åberg, L.; Sjödén, P.O. Attitudes towards organic foods among swedish consumers. Br. Food J. 2001, 103, 209-227. [CrossRef]

48. Nguyen, T.N.; Lobo, A.; Greenland, S. Energy efficient household appliances in emerging markets: The influence of consumers values and knowledge on their attitudes and purchase behaviour. Int. J. Consum. Stud. 2017, 41, 167-177. [CrossRef] 
49. Nguyen, T.N.; Lobo, A.; Greenland, S. Pro-environmental purchase behaviour: The role of consumers' biospheric values. J. Retail. Consum. Serv. 2016, 33, 98-108. [CrossRef]

50. Steg, L. Values, norms, and intrinsic motivation to act proenvironmentally. Annu. Rev. Environ. Resour. 2016, 41, 277-292. [CrossRef]

51. Perlaviciute, G.; Steg, L. The influence of values on evaluations of energy alternatives. Renew. Energy 2015, 77, 259-267. [CrossRef]

52. Van der Werff, E.; Steg, L.; Keizer, K. The value of environmental self-identity: The relationship between biospheric values, environmental self-identity and environmental preferences, intentions and behaviour. J. Environ. Psychol. 2013, $34,55-63$. [CrossRef]

53. Liobikienè, G.; Mandravickaitè, J.; Bernatonienè, J. Theory of planned behavior approach to understand the green purchasing behavior in the eu: A cross-cultural study. Ecol. Econ. 2016, 125, 38-46. [CrossRef]

54. Lodorfos, G.N.; Dennis, J. Consumers' intent: In the organic food market. J. Food Prod. Mark. 2008, 14, 17-38. [CrossRef]

55. Arvola, A.; Vassallo, M.; Dean, M.; Lampila, P.; Saba, A.; Lähteenmäki, L.; Shepherd, R. Predicting intentions to purchase organic food: The role of affective and moral attitudes in the theory of planned behaviour. Appetite 2008, 50, 443-454. [CrossRef]

56. Chen, M.-F. Consumer attitudes and purchase intentions in relation to organic foods in taiwan: Moderating effects of food-related personality traits. Food Qual. Prefer. 2007, 18, 1008-1021. [CrossRef]

57. Kirk, J.; Soffe, R.; Hall, R. Attitudes and beliefs toward organic meat in the south west of england. In Organic Meat and Milk from Ruminants; Kyriazakis, I., Zervas, G., Eds.; Wageningen Academic Publishers: Wageningen, The Netherlands, 2001 ; pp. 65-71.

58. Wong, S.S.; Aini, M.S. Factors influencing purchase intention of organic meat among consumers in klang valley, malaysia. Int. Food Res. J. 2017, 24, 767-778.

59. Hill, H.; Lynchehaun, F. Organic milk: Attitudes and consumption patterns. Br. Food J. 2002, 104, 526-542. [CrossRef]

60. Barbarossa, C.; De Pelsmacker, P. Positive and negative antecedents of purchasing eco-friendly products: A comparison between green and non-green consumers. J. Bus. Ethics 2016, 134, 229-247. [CrossRef]

61. Nguyen, T.N.; Phan, T.T.H.; Cao, T.K.; Nguyen, H.V. Green purchase behavior: Mitigating barriers in developing countries. Strateg. Dir. 2017, 33, 4-6. [CrossRef]

62. Tandon, A.; Jabeen, F.; Talwar, S.; Sakashita, M.; Dhir, A. Facilitators and inhibitors of organic food buying behavior. Food Qual. Prefer. 2021, 88, 104077. [CrossRef]

63. Tanner, C.; Kast, S.W. Promoting sustainable consumption: Determinants of green purchases by swiss consumers. Psychol. Mark. 2003, 20, 883-902. [CrossRef]

64. Apostolidis, C.; McLeay, F. To meat or not to meat? Comparing empowered meat consumers' and anti-consumers' preferences for sustainability labels. Food Qual. Prefer. 2019, 77, 109-122. [CrossRef]

65. McEachern, M.G.; Schröder, M.J.A. The role of livestock production ethics in consumer values towards meat. J. Agric. Environ. Ethics 2002, 15, 221-237. [CrossRef]

66. Baumeister, R.F.; Stillwell, A.M.; Heatherton, T.F. Guilt: An interpersonal approach. Psychol. Bull. 1994, 115, 243-267. [CrossRef]

67. Kugler, K.; Jones, W.H. On conceptualizing and assessing guilt. J. Personal. Soc. Psychol. 1992, 62, 318-327. [CrossRef]

68. Wang, F.; Basso, F. "Animals are friends, not food": Anthropomorphism leads to less favorable attitudes toward meat consumption by inducing feelings of anticipatory guilt. Appetite 2019, 138, 153-173. [CrossRef] [PubMed]

69. Behling, O.; Law, K.S. Translating Questionnaires and Other Research Instruments: Problems and Solutions; Sage: Thousand Oaks, CA, USA, 2000

70. Dean, M.; Raats, M.M.; Shepherd, R. The role of self-identity, past behavior, and their interaction in predicting intention to purchase fresh and processed organic food. J. Appl. Soc. Psychol. 2012, 42, 669-688. [CrossRef]

71. Nguyen, T.N.; Lobo, A.; Greenland, S. The influence of vietnamese consumers' altruistic values on their purchase of energy efficient appliances. Asia Pac. J. Mark. Logist. 2017, 29, 759-777. [CrossRef]

72. Le, A.N.H.; Tran, M.D.; Nguyen, D.P.; Cheng, J.M.S. Heterogeneity in a dual personal values-dual purchase consequences-green consumption commitment framework. Asia Pac. J. Mark. Logist. 2019, 31, 480-498. [CrossRef]

73. Thøgersen, J.; Zhou, Y. Chinese consumers' adoption of a 'green' innovation-The case of organic food. J. Mark. Manag. 2012, 28, 313-333. [CrossRef]

74. Zikmund, W.G.; Alessandro, S.; Winzar, H.; Lowe, B.; Babin, B.J. Marketing Research: Asia-Pacific Edition; Cengage Learning: South Melbourne, Australia, 2014.

75. Zikmund, W.G.; Babin, B.J.; Carr, J.C.; Griffin, M. Business Research Methods, 8th ed.; South-Western Cengage Learning: Mason, OH, USA, 2010.

76. GSO. Statistical Data. 2020. Available online: https://www.gso.gov.vn/en/statistical-data/ (accessed on 12 December 2020).

77. Nguyen, T.N.; Nguyen, H.V.; Lobo, A.; Dao, T.S. Encouraging vietnamese household recycling behavior: Insights and implications. Sustainability 2017, 9, 179. [CrossRef]

78. MacKenzie, S.B.; Podsakoff, P.M. Common method bias in marketing: Causes, mechanisms, and procedural remedies. J. Retail. 2012, 88, 542-555. [CrossRef]

79. Podsakoff, P.M.; MacKenzie, S.B.; Podsakoff, N.P. Sources of method bias in social science research and recommendations on how to control it. Annu. Rev. Psychol. 2012, 63, 539-569. [CrossRef]

80. Malhotra, N.K.; Kim, S.S.; Patil, A. Common method variance in is research: A comparison of alternative approaches and a reanalysis of past research. Manag. Sci. 2006, 52, 1865-1883. [CrossRef] 
81. Cohen, J. Statistical Power Analysis for the Behavioral Sciences; Routledge: New York, NY, USA, 1988.

82. Hair, J.F.; Black, W.C.; Babin, B.J.; Anderson, R.E. Multivariate Data Analysis, 7th ed.; Prentice Hall: Upper Saddle River, NJ, USA, 2010.

83. Byrne, B.M. Structural Equation Modeling with Amos: Basic Concepts, Applications, and Programming, 2nd ed.; Routledge: New York, NY, USA, 2010.

84. Chin, W.W.; Gopal, A.; Salisbury, W.D. Advancing the theory of adaptive structuration: The development of a scale to measure faithfulness of appropriation. Inf. Syst. Res. 1997, 8, 342-367. [CrossRef]

85. Grewal, R.; Cote, J.A.; Baumgartner, H. Multicollinearity and measurement error in structural equation models: Implications for theory testing. Mark. Sci. 2004, 23, 519-529. [CrossRef]

86. Yadav, R.; Pathak, G.S. Intention to purchase organic food among young consumers: Evidences from a developing nation. Appetite 2016, 96, 122-128. [CrossRef] [PubMed]

87. Thøgersen, J. Country differences in sustainable consumption: The case of organic food. J. Macromark. 2010, 30, 171-185. [CrossRef]

88. Sparks, P.; Shepherd, R. Self-identity and the theory of planned behavior: Assesing the role of identification with "green consumerism". Soc. Psychol. Q. 1992, 55, 388-399. [CrossRef]

89. Hofstede, G. Culture's Consequences: Comparing Values, Behaviors, Institutions, and Organizations across Nations, 2nd ed.; Sage: Thousand Oaks, CA, USA; London, UK, 2001.

90. Bosona, T.; Gebresenbet, G. Swedish consumers' perception of food quality and sustainability in relation to organic food production. Foods 2018, 7, 54. [CrossRef]

91. Thøgersen, J.; Pedersen, S.; Aschemann-Witzel, J. The impact of organic certification and country of origin on consumer food choice in developed and emerging economies. Food Qual. Prefer. 2019, 72, 10-30. [CrossRef]

92. Moons, I.; De Pelsmacker, P. Emotions as determinants of electric car usage intention. J. Mark. Manag. 2012, 28, 195-237. [CrossRef]

93. Moon, W.; Balasubramanian, S.; Rimal, A.P. Agro-biotechnology and organic food purchase in the united kingdom. Br. Food J. 2005, 107, 84-97.

94. Kamenidou, I.E.; Stavrianea, A.; Bara, E.-Z. Generational differences toward organic food behavior: Insights from five generational cohorts. Sustainability 2020, 12, 2299. [CrossRef]

95. Azzurra, A.; Massimiliano, A.; Angela, M. Measuring sustainable food consumption: A case study on organic food. Sustain. Prod. Consum. 2019, 17, 95-107. [CrossRef]

96. Haase, J.; Wiedmann, K.-P.; Bettels, J.; Labenz, F. How to best promote my product? Comparing the effectiveness of sensory, functional and symbolic advertising content in food marketing. Br. Food J. 2018, 120, 1792-1806. [CrossRef]

97. Sultan, P.; Tarafder, T.; Pearson, D.; Henryks, J. Intention-behaviour gap and perceived behavioural control-behaviour gap in theory of planned behaviour: Moderating roles of communication, satisfaction and trust in organic food consumption. Food Qual. Prefer. 2020, 81, 103838. [CrossRef]

98. Thøgersen, J.; de Barcellos, M.D.; Perin, M.G.; Zhou, Y. Consumer buying motives and attitudes towards organic food in two emerging markets: China and brazil. Int. Mark. Rev. 2015, 32, 389-413. [CrossRef] 